\title{
Genetic testing in steroid-resistant nephrotic syndrome: why, who, when and how?
}

\author{
Rebecca Preston $^{1} \cdot$ Helen M. Stuart ${ }^{2,3} \cdot$ Rachel Lennon $^{1,4}$
}

Received: 21 April 2017 /Revised: 24 October 2017 / Accepted: 25 October 2017 / Published online: 27 November 2017

(C) The Author(s) 2017. This article is an open access publication

\begin{abstract}
Steroid-resistant nephrotic syndrome (SRNS) is a common cause of chronic kidney disease in childhood and has a significant risk of rapid progression to end-stage renal disease. The identification of over 50 monogenic causes of SRNS has revealed dysfunction in podocyte-associated proteins in the pathogenesis of proteinuria, highlighting their essential role in glomerular function. Recent technological advances in high-throughput sequencing have enabled indication-driven genetic panel testing for patients with SRNS. The availability of genetic testing, combined with the significant phenotypic variability of monogenic SRNS, poses unique challenges for clinicians when directing genetic testing. This highlights the need for clear clinical guidelines that provide a systematic approach for mutational screening in SRNS. The likelihood of identifying a causative mutation is inversely related to age at disease onset and is increased with a positive family history or the presence of extra-renal manifestations. An unequivocal molecular diagnosis could allow for a personalised treatment approach with weaning of immunosuppressive therapy, avoidance of renal biopsy and provision of accurate, well-informed genetic counselling. Identification of novel causative mutations will continue to unravel the pathogenic mechanisms of glomerular disease and provide new insights into podocyte biology and glomerular function.
\end{abstract}

Keywords Steroid-resistant nephrotic syndrome · Focal segmental glomerulosclerosis · Monogenic · Mutational screening · Genetic testing

\section{Introduction}

Nephrotic syndrome (NS) comprises a heterogeneous group of disorders characterised by hypoalbuminaemia, oedema and hyperlipidaemia. This primarily reflects dysfunction of the normally

Rachel Lennon

Rachel.Lennon@manchester.ac.uk

1 Division of Cell Matrix Biology, Wellcome Trust Centre for Cell-Matrix Research, School of Biological Sciences, Faculty of Biology Medicine and Health, University of Manchester, Manchester, UK

2 Division of Evolution and Genomic Sciences, School of Biological Sciences, Faculty of Biology, Medicine and Health, The University of Manchester, Manchester, UK

3 Manchester Centre for Genomic Medicine, St. Mary's Hospital, Central Manchester Foundation NHS Trust, Manchester Academic Health Science Centre (MAHSC), Manchester, UK

4 Department of Paediatric Nephrology, Royal Manchester Childrens' Hospital, Central Manchester University Hospitals NHS Foundation Trust, Manchester Academic Health Science Centre, Manchester, UK size- and charge-selective glomerular filtration barrier (GFB), with resultant loss of protein into the urine. NS is the most common glomerular disease of childhood, with an estimated incidence of approximately 1-2 per 100,000 children [1, 2], accounting for approximately $10 \%$ of early-onset chronic kidney disease [3]. Classification is based on the response to treatment with glucocorticoids ( $\mathrm{Gc}$ ) as either steroid-sensitive (where Gc induces remission) or steroid-resistant NS (SRNS). Approximately $80 \%$ of paediatric NS cases respond to Gc, with the remaining $20 \%$ being steroid-resistant [4]. SRNS may be further characterised by renal histology, with the majority of cases showing focal segmental glomerulosclerosis (FSGS) [5] and, to a lesser extent, minimal change disease (MCD) or diffuse mesangial sclerosis (DMS). Furthermore, SRNS may occur as an isolated kidney disease or, less frequently, as a syndromic disorder associated with extra-renal manifestations. There is significant heterogeneity in the onset and clinical course of SRNS, and neither the clinical features nor the histological pattern predicts therapy response. However, SRNS is more likely to show resistance to a range of immunosuppressive agents [6] and progress to end-stage renal disease (ESRD) at a faster rate $[4,7]$. 
The exponential discovery of genes implicated in SRNS has helped to build understanding about the molecular mechanisms of glomerular filtration. Mutations in genes encoding podocyte-associated proteins have been implicated in about $30 \%$ of SRNS cases in children [8-10] (Table 1), and identification of these monogenic defects has provided fundamental insights into the pathogenesis of SRNS. Importantly, monogenic SRNS exhibits significant clinical and histological heterogeneity, even with identical causative mutations, and is initially indistinguishable from idiopathic NS. However, children with monogenic SRNS experience higher rates of resistance to immunosuppression and lower rates of disease reoccurrence after renal transplantation $[6,63]$.

With the ever-increasing number of genes implicated in SRNS and significant variability in clinical phenotype, clinicians face difficulties when presented with a child with SRNS. Mutation detection in such patients allows for a more personalised treatment approach; that is, the possibility of avoiding immunosuppressive therapy, thereby preventing associated side effects, and the potential to better predict posttransplant reoccurrence. A genetic diagnosis may also allow screening for, and early management of, associated medical conditions, such as glaucoma in Nail-Patella syndrome. In addition, a molecular diagnosis offers scope for more accurate genetic counselling, risk stratification and prenatal diagnosis for affected families. Currently, there are no clear guidelines detailing the clinical utilisation, relevance and costeffectiveness of mutational screening for children with SRNS. Here, we discuss the most common causes of monogenic SRNS and link these causes to clinical phenotypes. We discuss the indications for genetic testing and propose a clinically useful approach for mutational screening in SRNS, with particular reference to who should undergo genetic testing, when this should be performed and how this should be carried out.

\section{Podocyte biology}

The GFB is composed of three interacting layers: the fenestrated endothelial cells, the glomerular basement membrane and the outer podocyte layer. Podocytes are highly specialised epithelial cells, and their interdigitating foot processes connect to form the slit diaphragm, a unique multiprotein cell junction structure which, through regulation of podocyte function, controls the ultrafiltration of molecules. Genetic advances in SRNS have unveiled dysfunction of podocyte- and slit diaphragm-associated proteins in the pathogenesis of proteinuria, highlighting their importance in maintaining GFB integrity. The discovery began with genes encoding the slit diaphragm proteins nephrin (NPHS1) and podocin (NPHS2) $[11,12]$. Since then, linkage analysis and next generation sequencing (NGS) have permitted the identification of over 50 genes implicated in SRNS, and this number continues to increase. Interestingly, the majority of encoded proteins map to distinct structural protein complexes and signalling pathways within the podocyte (Fig. 1). A thorough functional analysis of these proteins is beyond the scope of this review, but readers are directed elsewhere for a more detailed evaluation [64].

\section{Genotype-phenotype correlations in monogenic SRNS}

Monogenic SRNS can be inherited in an autosomal recessive, autosomal dominant or mitochondrial manner, and can occur as an isolated renal disease or as part of a multisystem disorder. Most cases of recessive disease are characterised by an early onset and high penetrance, and they are not infrequently associated with extra-renal malformations. In contrast, the main causes of dominant disease are associated with a later onset and incomplete penetrance, and the patients may remain asymptomatic. The genes associated with SRNS identified to date and their associated phenotypes are presented in Table 1. In the following sections, we outline the most common monogenic causes of SRNS, according to age of onset.

\section{Congenital NS}

Congenital NS (CNS), which presents within the first 3 months of life, is commonly associated with causative mutations. Indeed, mutations have been identified in 75 $100 \%$ of cases of CNS $[8,10,65,66]$. Causative mutations appear to largely occur in one of five genes (NPHS1, NPHS2, WT1, LAMB2 and PLCE1). NPHS1, encoding nephrin, is the main gene implicated in CNS, and mutation is responsible for the autosomal recessive Finnish type (CNF), which typically has a severe phenotype with massive proteinuria and rapid progression to ESRD [11]. However, the NPHS1 mutation detection rate remains high amongst non-Finnish cases of CNS [8, 10, 65]. Mutations in the NPHS2 gene, encoding podocin, are also responsible for a significant number of CNS cases, and the phenotype varies from the severe CNF presentation to milder disease with onset of proteinuria occurring later than in those with NPHS1 mutations [4, 66, 67]. Mutations in the PLCE1,WT1 and LAMB2 genes have also been detected in patients presenting with isolated CNS; mutations in these genes will be discussed in more detail in the next section.

\section{Infantile and childhood NS}

Monogenic NS, which presents in infancy (from 4 to 12 months of life) and during childhood, is most commonly attributed to mutations in the NPHS2 gene, encoding podocin 
$[8,68]$. There is a recognised genotype to phenotype correlation that explains this phenotypic variability $[12,66,69]$. Recent whole-exome sequencing performed on a paediatric cohort of SRNS patients revealed the mean age of onset associated with NPHS2 mutations to be approximately 6 years [8]. That said, it is clearly important to consider NPHS2 mutation as a cause for SRNS in a child of any age and, conversely, to expect a low rate of NPHS2 mutations in certain ethnic groups, namely Chinese, Japanese and Korean [10, 70]. Additionally, NPHS1 mutations have been identified in infants and children presenting with SRNS, with the rarer hypomorphic mutations being associated with a milder lateonset phenotype $[8,71,72]$. Thus, mutations in this gene should be considered in all paediatric age groups.

Mutations in PLCE1 (encoding phospholipase C epsilon-1) typically cause isolated DMS, with patients presenting with severe, early-onset SRNS and rapid progression to ESRD [13]. Again, significant clinical heterogeneity exists, with PLCE1 mutations manifesting from birth and throughout childhood, with both FSGS or DMS found histologically $[73,74]$.

WT1 encodes Wilms' tumour 1, a transcription factor and key kidney development gene. Mutations in WT1 cause isolated and syndromic SRNS, which will be discussed later in this review. Previous studies have estimated WT1 mutations to account for approximately $6 \%$ of sporadic SRNS cases in childhood, manifesting at any age, depending on the underlying mutation $[8,66,75,76]$. Genotype-phenotype correlations have been drawn from specific WT1 mutations. Of these, certain mutations cause early-onset, severe disease with DMS histologically, or alternatively, late-onset SRNS with FSGS histologically and slower progression to ESRD [75]. Interestingly, isolated SRNS may result from a wide range of WT1 sequence variations, which are associated with variable expression and incomplete penetrance [75]. It is important to stress that WT1-related nephropathy may be an isolated disease with no associated comorbidities or it may be an initial symptom of syndromic SRNS with extra-renal features manifesting later.

Although mutations in TRPC6 and ACTN4 are typically associated with autosomal dominant late-onset disease, as discussed below, there are reports of both infantile and childhood-onset SRNS caused by mutations in these genes.

\section{Late-onset NS}

Autosomal dominant SRNS typically presents later in life, in adolescence or adulthood, and has significant phenotypic variability. The overall mutation detection rate remains substantial, approaching $25 \%$ in adolescence and $12 \%$ in adulthood, but it is lower than cases presenting earlier in childhood [8, 65]. The main genes implicated in late-onset SRNS, which presents in adolescence, include NPHS2, TRPC6, INF2 and ACTN4 [31, 65, 68, 77, 78]. TRPC6, encodes a transient receptor potential cation channel and was originally identified as causing autosomal dominant FSGS, presenting in adolescence and early adulthood and showing relatively rapid progression to ESRD. Since then, TRPC6 mutations have been implicated in childhood-onset FSGS, and even SRNS presenting within the first year of life, with variable disease severity $[8,10,77$, $79,80]$. Similarly, mutations in ACTN4, which encodes alphaactinin 4, typically cause late-onset FSGS with slow progression to ESRD [29, 81], but mutations in this gene have been reported in children presenting with SRNS and rapid progression to ESRD $[8,82]$. Mutations in INF2, encoding inverted formin 2 , were originally identified in patients with autosomal dominant SRNS, with age of onset ranging from adolescence and throughout adulthood [31, 83]. Although INF2 mutations typically result in isolated FSGS, they have also been detected in a subgroup of patients with associated Charcot-MarieTooth neuropathy [84]. Specific NPHS2 mutations may manifest late, in adolescence or adulthood; the common variant R229Q may result in late-onset SRNS in compound heterozygotes with specific second mutations [85].

\section{Syndromic SRNS and mitochondrial disorders}

Syndromic SRNS is associated with extra-renal manifestations and most commonly occurs due to mutations in genes encoding nuclear proteins (WT1, LMX1B, SMARCL1, WDR73), glomerular basement membrane and adhesion components (LAMB2, ITGA3, ITGB4), actin cytoskeleton components (MYH9) and lysosomal (SCARB2) and mitochondrial proteins (COQ2, COQ6, PDSS2, MTTL1, ADCK4). Table 2 lists the major extrarenal manifestations associated with gene defects causing syndromic SRNS; if extra-renal manifestations are present, it is highly likely that a causative mutation will be identified. A full description of syndromic SRNS is beyond the scope of this review but readers are directed to several detailed reviews for a thorough discussion $[5,20$, $21,44,45,50,55,84,86,87]$.

WT1 mutations are associated with a spectrum of significant extra-renal manifestations, including urogenital abnormalities and malignancy. Mutations in the KTS (splice insertion) site are associated with Frasier syndrome, characterised by childhood-onset SRNS, histologically characterised FSGS, male-to-female sex reversal and increased risk of gonadoblastoma [18, 75]. Missense mutations in exons 8 and 9 (affecting the zinc finger domains) are associated with Denys-Drash syndrome, characterised by infantile-onset SRNS, histologically characterised DMS, sex reversal, gonadoblastoma and Wilms' tumour [75]. Large genomic rearrangements disrupting WT1 and the neighbouring PAX6 result in WAGR syndrome (Wilms' 
Table 1 Monogenic causes of steroid-resistant nephrotic syndrome identified to date, including details of associated clinical phenotype, most frequently observed renal histological lesion and likely mode of inheritance

\begin{tabular}{llll}
\hline Gene & Protein & Phenotype & $\begin{array}{l}\text { Mode of } \\
\text { inheritance }\end{array}$ \\
\hline
\end{tabular}

Slit diaphragm-associated proteins

$\begin{array}{llllr}\text { NPHS1 } & \text { Nephrin } & \text { CNS (Finnish type), SRNS (early onset) } & \text { AR } & \text { PTRD, PMS, } \\ \text { FSGS, MCD } & \text { [11] } \\ \text { NPHS2 } & \text { Podocin } & \text { CNS, SRNS (early and late onset) } & \text { AR } & \text { FSGS, MCD } \\ \text { PLCE1 } & \text { Phospholipase C epsilon 1 } & \text { CNS, SRNS (early onset) } & \text { AR } & \text { DMS, FSGS } \\ \text { CD2AP } & \text { CD2-associated protein } & \text { SRNS } & \text { AD, AR } & \text { FSGS } \\ \text { TRPC6 } & \text { Transient receptor potential channel C6 } & \text { SRNS (late onset) } & \text { AD } & \text { FSGS } \\ \text { CRB2 } & \text { Crumbs family member 2 } & \text { SRNS } & \text { AR } & \text { FSGS } \\ \text { FAT1 } & \text { FAT atypical cadherin 1 } & \text { FSGS, neurological involvement } & \text { AR } & \text { Variable }\end{array}$

Nuclear proteins and transcription factors

$\begin{array}{ll}\text { WT1 } & \text { Wilms' tumour protein } 1 \\ \text { LMX1B } & \text { LIM homeobox transcription factor } 1 \beta \\ \text { SMARCL1 } & \text { SMARCA-like protein } \\ \text { NUP93 } & \text { Nuclear pore complex protein } 93 \\ \text { NUP107 } & \text { Nuclear pore complex protein } 107 \\ \text { NUP205 } & \text { Nuclear pore complex protein } 205 \\ X P O 5 & \text { Exportin } 5 \\ \text { E2F3 } & \text { E2F transcription factor } \\ \text { NXF5 } & \text { Nuclear RNA export Factor } 5 \\ P A X 2 & \text { Paired box protein } 2 \\ L M N A & \text { Lamin A and C } \\ W D R 73 & \text { WD repeat domain } 73\end{array}$

Denys Drash, Frasier, isolated SRNS +/-

$\mathrm{AD}, \mathrm{AR}$

FSGS, DMS

$[18,19]$

ambiguous genitalia

Nail-patella syndrome, isolated SRNS

Schimke immuno-osseous dysplasia

$\mathrm{AD}$

FSGS

[20]

SRNS

AR

FSGS

SRNS (early onset)

FSGS

SRNS

AR FSGS

SRNS

AR FSGS

FSGS, mental retardation (gene deletion)

AR $\quad$ FSGS

FSGS, co-segregating heart block

FSGS

Isolated SRNS (adult-onset)

XLR

FSGS

Familial partial lipodystrophy, FSGS

$\mathrm{AD}$

FSGS

Galloway-Mowat syndrome

FSGS

$\mathrm{AD}$

FSGS, DMS

Cytoskeletal, scaffold and membrane proteins

$\begin{array}{ll}\text { ACTN4 } & \alpha \text {-actinin } 4 \\ \text { MYH9 } & \text { Myosin heavy chain 9, non-muscle } \\ \text { INF2 } & \text { Inverted formin 2 } \\ \text { MYO1E } & \text { Myosin 1E } \\ \text { MAGI2 } & \begin{array}{c}\text { Membrane Associated Guanylate Kinase, } \\ \text { inverted 2 }\end{array} \\ \text { ANLN } & \text { Anillin actin binding protein }\end{array}$

ARHGAP24 $\quad$ Rho GTPase-activating protein 24

ARHGDIA Rho GDP dissociation inhibitor alpha

$K A N K$ 1/2/4 Kidney ankyrin repeat-containing protein

SYNPO Synaptopodin

PTPRO Protein-tyrosine phosphatase-R O

EMP2 Epithelial membrane protein 2

APOL1 Apolipoprotein L1

CUBN Cubilin

PODXL Podocalyxin

SRNS (late onset)
MYH9-related disorders, SRNS
SRNS, Charcot-Marie-Tooth disease
SRNS
CNS, SRNS
SRNS (adult-onset)
SRNS (adult-onset)
SRNS (CNS), seizures, cortical blindness
SRNS +/- haematuria
FSGS
SRNS (childhood onset)
SRNS (childhood onset)
Susceptibility to SRNS
SRNS
FSGS

$\begin{array}{ll}\text { AD } & \text { FSGS } \\ \text { AD } & \text { FSGS } \\ \text { AD } & \text { FSGS } \\ \text { AR } & \text { FSGS } \\ \text { AR } & \text { MCD } \\ \text { AD } & \text { FSGS } \\ \text { AD } & \text { FSGS } \\ \text { AR } & \text { FSGS } \\ \text { AR } & \text { FSGS } \\ \text { AD } & \text { FSGS } \\ \text { AR } & \text { FSGS, MCD } \\ \text { AR } & \text { FSGS } \\ \text { Biallelic } & \text { FSGS } \\ \text { AR } & \text { FSGS } \\ \text { AD } & \text { FSGS }\end{array}$

Glomerular basement membrane-associated proteins

$\begin{array}{ll}\text { LAMB2 } & \text { Laminin subunit } \beta 2 \\ \text { ITGB4 } & \text { Integrin } \beta 4 \\ \text { ITGA3 } & \text { Integrin } \alpha 3\end{array}$

Pierson syndrome, isolated SRNS

AR DMS, FSGS

[44]

Epidermolysis bullosa, SRNS, lung

AR

FSGS disease

Epidermolysis bullosa, SRNS, lung disease

AR FSGS

[46]

COL4A3/4/5 Type IV collagen $\alpha 3, \alpha 4, \alpha 5$

$\mathrm{AD}, \mathrm{AR}, \mathrm{XL} \quad \mathrm{FSGS}$ 
Table 1 (continued)

\begin{tabular}{|c|c|c|c|c|c|}
\hline Gene & Protein & Phenotype & $\begin{array}{l}\text { Mode of } \\
\text { inheritance }\end{array}$ & Histology & Reference \\
\hline GPC5 & Glypican 5 & NS (adult onset) & Risk gene & Variable & {$[48]$} \\
\hline$C D 151$ & CD151 antigen & FSGS, bullous skin lesions, deafness & $\mathrm{AR}$ & FSGS & [49] \\
\hline \multicolumn{6}{|c|}{ Mitochondrial proteins } \\
\hline COQ2 & Coenzyme Q2 & $\begin{array}{l}\mathrm{CoQ}_{10} \text { deficiency, SRNS +/- } \\
\text { encephalopathy }\end{array}$ & $\mathrm{AR}$ & $\mathrm{CG}$ & {$[50]$} \\
\hline COQ6 & Coenzyme Q6 & $\mathrm{CoQ}_{10}$ deficiency, SRNS and deafness & $\mathrm{AR}$ & FSGS, DMS & {$[51]$} \\
\hline PDSS2 & Prenyl-diphosphate synthase subunit 2 & $\begin{array}{l}\mathrm{CoQ}_{10} \text { deficiency, SRNS, Leigh } \\
\text { syndrome }\end{array}$ & $\mathrm{AR}$ & FSGS & {$[52]$} \\
\hline$A D C K 4$ & AarF domain containing kinase 4 & $\mathrm{CoQ}_{10}$ biosynthesis disruption & $\mathrm{AR}$ & FSGS & {$[53]$} \\
\hline MTTL1 & Mitochondrial tRNA 1 & MELAS, diabetes, deafness, SRNS & Mitochondrial & FSGS & {$[54]$} \\
\hline \multicolumn{6}{|c|}{ Lysosomal and endocytic proteins } \\
\hline$S C A R B 2$ & Scavenger receptor class B, member 2 & $\begin{array}{l}\text { Action myoclonus-renal failure syn- } \\
\text { drome }\end{array}$ & $\mathrm{AR}$ & FSGS & {$[55]$} \\
\hline OCRL1 & Oculocerebrorenal syndrome of Lowe & Dent-2 disease, Lowe syndrome, SRNS & XLR & FSGS & {$[56]$} \\
\hline \multicolumn{6}{|c|}{ Metabolic and cytosolic proteins } \\
\hline ZMPSTE24 & Zinc metallopeptidase STE24 & Mandibuloacral dysplasia & $\mathrm{AR}$ & FSGS & {$[57]$} \\
\hline$P M M 2$ & Phosphomannomutase 2 & Congenital defect of glycosylation & $\mathrm{AR}$ & $\mathrm{CG}$ & {$[58]$} \\
\hline$A L G 1$ & Asparagine-linked glycosylation 1 & Congenital defect of glycosylation & $\mathrm{AR}$ & FSGS & {$[59]$} \\
\hline TTC21B & Tetratricopeptide repeat protein $21 \mathrm{~B}$ & FSGS & $\mathrm{AR}$ & FSGS & {$[60]$} \\
\hline $\mathrm{CFH}$ & Complement factor $\mathrm{H}$ & SRNS & $\mathrm{AR}$ & FSGS & {$[61]$} \\
\hline$D G K E$ & Diacylglycerol kinase epsilon & NS & $\mathrm{AR}$ & FSGS & {$[62]$} \\
\hline
\end{tabular}

AD, Autosomal dominant; AR, autosomal recessive; CG, collapsing glomerulopathy; CNS, congenital nephrotic syndrome; DMS, diffuse mesangial sclerosis; FSGS, focal segmental glomerulosclerosis; MCD, minimal change disease; MELAS, Mitochondrial encephalomyopathy, lactic acidosis, and stroke-like episodes; NS, nephrotic syndrome; PMS, progressive mesangial sclerosis; PTRD, proximal tubule radial dilatation; SRNS, steroid-resistant nephrotic syndrome; XL, X-linked

tumour, aniridia, genito-urinary abnormalities and mental retardation) [75]. Although these genotype-phenotype correlations have been clearly described, it is important to note that there remains significant phenotypic variability with respect to extra-renal manifestations of WT1-associated disease. Furthermore, histopathological heterogeneity is noted even amongst carriers of the same genetic abnormality [75].

$L A M B 2$ and $L M X 1 B$ mutations typically cause Pierson syndrome and Nail-Patella syndrome, respectively, but have also been identified in isolated congenital, infantile and childhood-onset SRNS [88, 89], and mutation in these genes should therefore be considered to be causative in these age groups.

Isolated SRNS may also be seen, although rarely, in certain mitochondrial cytopathies, including MELAS (mitochondrial myopathy, encephalopathy, lactic acidosis and stroke-like episodes) caused by MTTL1 mutations [54] and coenzyme $\mathrm{Q}_{10}$ deficiency [90]. Coenzyme $\mathrm{Q}_{10}$ deficiency due to mutations in $C O Q^{2}$ and $C O Q 6$ may cause an isolated or syndromic nephropathy [51]. Mutations in PDSS2 cause Leigh syndrome but may also cause isolated SRNS [52].

$A D C K 4$ mutations have been found to cause isolated SRNS with histologically characterised FSGS, manifesting from infancy through to early adulthood [53]. In contrast to previous studies [9], in a large multicentre cohort of Chinese paediatric patients with SRNS, ADCK4 was found to be the most commonly mutated causative gene, responsible for SRNS presenting as early as the congenital period, but most frequently during childhood [10].

Interestingly, there have been reports of patients with coenzyme $\mathrm{Q}_{10}$ deficiency and $A D C K 4$ mutation whereby interventional treatment with $\mathrm{COQ}_{10}$ supplementation has been shown to modify disease progression $[53,90]$.

\section{Genetic testing; why?}

Genetic testing in NS has important clinical and non-clinical implications. Confirmation of a genetic defect can personalise 
Fig. 1 Genetic mutations associated with steroid-resistant nephrotic syndrome (SRNS) grouped according to location and function within the glomerular filtration barrier. For full names of proteins encoded by genes, please refer to Table 1

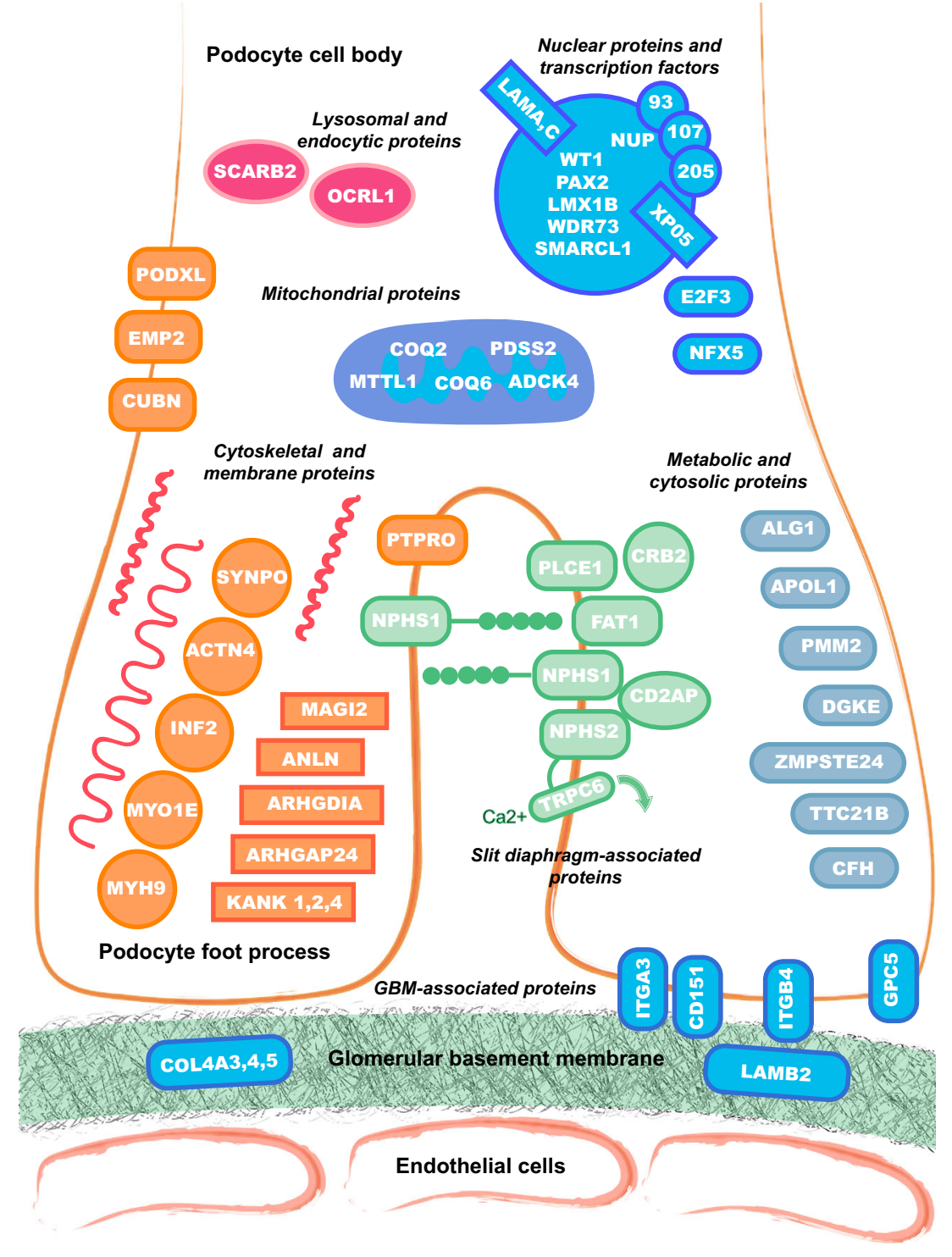

SRNS management by means of predicting clinical course, weaning immunosuppression, avoiding renal biopsy, planning renal transplantation, providing genetic counselling and offering potential antenatal and pre-symptomatic diagnosis. In addition to these clinical benefits, identification of known and novel pathogenic variants implicated in monogenic SRNS will better define genotype-phenotype correlations, advance our understanding of the GFB and generate novel avenues for the in vitro and in vivo study of the pathophysiological mechanisms of proteinuria.

\section{Immunosuppression}

Several studies highlight that monogenic SRNS is largely steroid resistant, irrespective of the causative mutation [6, 69, 91]. Subsequent management of such patients often includes various immunosuppressive agents, all with associated adverse side effects and often limited clinical benefit $[6,91]$.
Indeed, in a recent paediatric cohort of sporadic SRNS, none of those with an identified causative mutation responded to immunosuppressive agents, compared to almost $60 \%$ of those without a mutation [6]. However, there are reports in the literature of a partial response to steroids, ciclosporin therapy or calcineurin inhibitors in patients with specific WT1, NPHS2, PLCE1 and TRPC6 mutations or mutations in the regulators of Rho-like GTPase (ARHGDIA, KANK 1, KANK 2 and $K A N K$ 3) [13, 92-94]. Nonetheless, given that responsiveness to immunosuppression is unlikely in monogenic SRNS, upon receiving a positive genetic test result, clinicians should consider weaning immunosuppression if no clinical benefit has been demonstrated, thus protecting patients from the potentially devastating side effects of such treatments. It is important to note that there have been reports of patients with monogenic SRNS partially responding to secondary immunosuppression [13, 92-94]; in such cases, it would be important to continue therapy whilst clinical improvement continues. 
Table 2 Syndromic steroidresistant nephrotic syndrome and associated extra-renal manifestations

\begin{tabular}{|c|c|c|}
\hline Gene & Disease & Extra-renal manifestations \\
\hline \multirow[t]{2}{*}{$W T 1$} & Denys-Drash syndrome & Urogenital abnormalities, ambiguous genitalia, nephroblastoma \\
\hline & Frasier syndrome & Gonadoblastoma, male pseudohermaphroditism \\
\hline$L A M B 2$ & Pierson's syndrome & Ocular abnormalities; microcoria \\
\hline$L M X 1 B$ & Nail-Patella syndrome & Skeletal defects, hypoplastic nails, absent patella, glaucoma \\
\hline SMARCL1 & $\begin{array}{l}\text { Schimke } \\
\text { immune-osseous dys- } \\
\text { plasia }\end{array}$ & $\begin{array}{l}\text { Spondyloepiphyseal dysplasia, T cell immunodeficiency, cerebral } \\
\text { infarcts, skin pigmentation }\end{array}$ \\
\hline$S C A R B 2$ & $\begin{array}{l}\text { Action myoclonus renal } \\
\text { failure }\end{array}$ & Progressive myoclonic epilepsy, tremor, ataxia \\
\hline$C O Q 2$ & $\mathrm{CoQ}_{10}$ deficiency & Progressive encephalomyopathy \\
\hline COQ6 & $\mathrm{CoQ}_{10}$ deficiency & Sensorineural hearing loss \\
\hline PDSS2 & Leigh syndrome & Hypotonia, ataxia, deafness, growth retardation \\
\hline WDR73 & $\begin{array}{l}\text { Galloway-Mowat } \\
\text { syndrome }\end{array}$ & Microcephaly, psychomotor impairment, seizures, hypotonia \\
\hline MTTL1 & MELAS & $\begin{array}{l}\text { Myopathy, encephalopathy, lactic acidosis, stroke-like episodes, } \\
\text { diabetes, deafness }\end{array}$ \\
\hline ITGA3 & Epidermolysis-associated & Epidermolysis bullosa, interstitial lung disease \\
\hline ITGB4 & Epidermolysis-associated & Epidermolysis bullosa, pyloric atresia \\
\hline МYH9 & $\begin{array}{l}\text { MYH9-related } \\
\text { syndromes }\end{array}$ & $\begin{array}{l}\text { Macrothrombocytopenia, mental retardation, sensorineural } \\
\text { deafness, cataracts }\end{array}$ \\
\hline INF2 & Charcot-Marie-Tooth & Chronic peripheral motor and sensory neuropathy \\
\hline ZMPSTE24 & Manibuloacral dysplasia & $\begin{array}{l}\text { Mandibular and clavicular hypoplasia, cutaneous atrophy, } \\
\text { lipodystrophy, acro-oestolysis }\end{array}$ \\
\hline
\end{tabular}

For names of encoded proteins and associated histology, please consult Table 1

\section{Novel interventional therapy and monitoring}

The discovery of rare monogenic causes of SRNS have revealed a small but significant cohort whose disease may be amenable to specific interventional treatment, thereby avoiding lengthy immunosuppression and delaying progression to ESRD. Patients with disease-causing mutations in genes encoding enzymes of the coenzyme $\mathrm{Q}_{10}$ pathway $(C O Q 2, C O Q 6$ and $A D C K 4)$ and in the $C U B N$ gene may respond to treatment with coenzyme $\mathrm{Q}_{10}$ and vitamin B12, respectively. Likewise, patients with ARHGDIA mutations, through modulation of Rac I-mineralocorticoid interactions, could theoretically respond to eplenerone (a mineralocorticoid-receptor antagonist) [36].

As highlighted in Table 2, many syndromic forms of SRNS have associated medical problems that may benefit from early recognition and management. An example is the WT1 mutation, which can predispose to malignancy, and the detection of such mutations should trigger monitoring for associated Wilms' tumour and gonadoblastoma. Given the latter entity is largely associated with sex reversal, a karyotype analysis should also be performed, especially in phenotypically female patients presenting with SRNS and primary amenorrhoea.

\section{Renal biopsy}

Renal histology has historically been utilised as a key diagnostic and prognostic criterion for children with SRNS, but emerging evidence reveals significant histological heterogeneity amongst monogenic causes of SRNS, demonstrating that biopsy findings may not correlate with genetic results $[8,95]$. Furthermore, there does not appear to be a notable difference in the frequency of histological lesions found in patients with or without a recognised genetic cause [6]. For these reasons, in cases of primary SRNS, rapid genetic testing has the potential to obviate the need for renal biopsy for diagnostic purposes and serves as a less invasive diagnostic method; this is of particular significance in the younger SRNS cohort, for whom a genetic aetiology is more likely. In the event of rapid genetic testing being inaccessible, renal histology may direct clinicians towards the most likely "culprit" gene; for example, if DMS is detected in an infant presenting with SRNS, it would be prudent to perform mutational analysis on certain genes (LAMB2, WT1, NPHS1, PLCE1) preferentially over others. However, clinical indications for renal biopsy do remain, such as atypical features suggestive of lupus nephritis, with histology providing useful information. Additionally, a histological diagnosis enables phenotype patterns to become better established and is therefore useful from a clinical research perspective.

\section{Disease reoccurrence post-transplantation}

There is a high risk of progression to ESRD in monogenic SRNS, with many patients requiring renal transplantation 
[96]. Several studies have highlighted a low risk of disease reoccurrence post-transplant when a genetic aetiology has been confirmed $[6,8,68,69,96,97]$. Conversely, there is a high risk of post-transplant disease reoccurrence in the idiopathic group; this is postulated to be caused by circulating factors [98, 99]. Given that the likelihood of post-transplant reoccurrence is minimal for genetic SRNS; after excluding the mutation in parents, a parental transplant can be planned, although in our experience this typically follows bilateral nephrectomy and an interval of time on dialysis. Posttransplantation prognosis is improved with living donor transplantation, which is associated with prolonged graft survival and decreased rejection rates as compared to deceased donor kidney transplantation.

\section{Genetic counselling}

Genetic counselling prior to testing should ensure that families are informed regarding potential outcomes and limitations of the chosen genetic test, including the discovery of variants of unknown significance and the potential for incidental findings. Possible benefits, including changes to medical management, should be discussed, as well as potential harms, including privacy, legal and social implication. These subjects are covered in the next section.

Making a molecular diagnosis has important implications for a family. It may enable accurate discussion of recurrence risk in future children and potential identification of presymptomatic individuals at risk [4]. Early referral to a clinical genetics service can facilitate identification of individuals at risk and genetic testing of family members as well as counselling in terms of family planning, prenatal diagnosis and preimplantation genetic diagnosis. Genetic screening in unaffected family members may be additionally important when planning a living related donor (LRD) renal transplant, especially in the case of autosomal dominant disease. When inheritance of a severe disease-causing mutation is likely, presymptomatic testing for proteinuria and genotyping at birth are avenues that should be discussed and offered to affected families. Ethical considerations of causing potentially unnecessary anxiety should be addressed, and families should be counselled on the benefits and risks of such an approach; that is, the benefits of providing a timely genetic diagnosis, and therefore active clinical management, versus the risks of testing for a disease which may never manifest or be mild in the event of incomplete penetrance or variable expression. Prenatal diagnosis could be offered in families with a known risk of severe NS, such as CNS, or in cases where elevated alpha-fetoprotein levels have been detected in maternal serum or amniotic fluid. It can be used to allow the family to make an informed decision about continuing a pregnancy or to allow preparation both by the family and medical professionals for the birth of an affected child.

\section{Risks of genetic testing}

In addition to the ethical and emotional considerations that must be addressed during genetic counselling, there are several other risks to the patient and their family who are considering genetic testing or receiving a genetic diagnosis. In the UK, genetic testing is usually paid for by the National Health Service, and in countries with a privatised medical system, health insurance policies often cover the cost of genetic testing performed at the request of a doctor. However, this is not always the case, and in some situations the significant cost, which can be over US $\$ 2000$, must be covered by the family. Furthermore, upon receiving a genetic diagnosis, the fear of insurance discrimination and the associated costs of enhanced insurance premiums represent a significant emotional and financial burden. Although there is legislation in place which protects those with a genetic disease from discrimination by health insurers, this does not always extend to protect patients from employment discrimination or the amplified costs of life, disability and long-term care insurance [100]. As part of the genetic counselling process, these issues should be discussed with affected families and informed consent obtained prior to genetic testing. A thorough discussion regarding the barriers to genetic testing in public health is beyond the scope of this review, but readers are directed to several useful articles for further information [100-104].

\section{Genetic testing; who?}

Having discussed the benefits of identifying a causative mutation in patients with SRNS, it is important to note that the overall burden of monogenic SRNS has yet to be fully delineated. Recent evidence estimates that a genetic aetiology is detected in approximately $30 \%$ of cases. A negative result does not exclude genetic disease as mutations may be missed, with sensitivity for genes covered by the test depending on methodology and analysis used. Alternatively, a mutation may be present in a gene not covered by the chosen test, for example a novel genetic association. This, combined with the profound clinical and pathological heterogeneity of genetic and idiopathic SRNS, highlights that universal genetic testing in SRNS is inappropriate and unlikely to be cost-effective. Rather, mutational screening should be directed towards those in whom a genetic aetiology is likely and should therefore be reserved for patients presenting with primary SRNS.

\section{Indications for genetic testing}

When accessible and affordable, mutational screening should be performed in all children presenting with primary SRNS. 
Even in young adults, the likelihood of detecting a causative mutation remains substantial, and when cost allows, mutational screening should also be offered to this cohort. However, when such an inclusive approach is not possible, there are certain indications in which a genetic cause for SRNS becomes more likely, and mutational screening should be performed as a priority. Given that the likelihood of detecting a causative mutation is inversely related to age of disease onset [105], mutational screening becomes increasingly important the earlier the disease manifests. Genotype-phenotype correlations clearly demonstrate that mutations in recessive genes are more frequently implicated in early-onset disease and that mutations in dominant genes are more frequently implicated in adult-onset disease. Although there may not be an obvious family history in early-onset disease, a positive family history in any age group indicates that monogenic SRNS is likely and should trigger mutational screening. Additionally, the likelihood of finding causative recessive mutations correlates directly with the degree of consanguinity [80]; thus, a history of consanguinity should prompt mutational screening. Finally, the presence of extra-renal manifestations suggestive of an underlying genetic syndrome (Table 2) makes screening of associated genes advisable.

The clinical indications for genetic testing in SRNS can be summarized as follows:

- Congenital or infantile-onset NS

- Childhood-onset NS

- Family history of NS

- Consanguinity

- Extra-renal manifestations.

\section{Genetic testing; when?}

Before undertaking genetic testing for SRNS, it is important that the potential detection of a causative mutation is likely to aid in diagnosis, alter clinical management, inform likely prognosis and provide information when stratifying risk for family members and delivering genetic counselling. In congenital- and infantile-onset NS, genetic testing should be considered before commencing immunosuppressive therapy or performing renal biopsy. Similarly, when genetic testing can be performed in a timely manner, early confirmation of a genetic diagnosis in childhood-onset SRNS would minimise the adverse effects of current therapies on the growing child. Pre-transplantation genetic testing will provide clinicians with information that may be helpful in predicting the risk of posttransplant reoccurrence and will therefore guide pre- and posttransplant management, especially when considering LRD kidney transplantation from family members.
To summarise, we suggest that genetic testing should be considered when important clinical decisions need to be made regarding the need for renal biopsy, the intensity and duration of immunosuppression and pre-transplantation therapy, and when syndromic SRNS is suspected.

\section{Genetic testing; how?}

Traditionally, genetic testing in diagnostic laboratories has employed Sanger sequencing, frequently in association with exon copy number analysis, to assess specific disease-related genes individually. In genetically heterogeneous disorders, with multiple causal genes, such as SRNS, this method can be expensive and time-consuming owing to the cost of screening multiple individual genes. The advent of high-throughput massively parallel sequencing (NGS methods) allows for a higher diagnostic yield, time savings and a reduction in cost $[105,106]$. Typically, diagnostic laboratories utilise a targeted capture of a 'panel' of genes of interest followed by sequencing on an NGS platform. Sanger sequencing still plays an important role for the confirmation of genetic variants identified via NGS and filling in of regions of poor coverage. The limitations of Sanger sequencing include the need to ensure both adequate coverage of regions of interest and adequate analysis to detect copy number variants such as exonic deletions. As with most Sanger sequencing approaches, this method will miss deep intronic or regulatory region variants unless specifically targeted.

Whole-exome sequencing (WES) or whole-genome sequencing (WGS) employ NGS methods to attempt to sequence the coding portion of the genome (the exome) or the entire genome, respectively. This approach is not limited to known candidate genes and therefore has the ability to identify mutations in novel genes, thereby expanding the heterogeneity of SRNS and enhancing our understanding of the pathogenesis and molecular mechanisms of proteinuria. WES is increasingly being implemented in the clinical setting, but its widespread application is limited by the amounts of data generated and the requirements for robust bioinformatics support and assessments of the pathogenicity of larger numbers of variants. When targeted capture utilised for WES gives sufficient coverage of the 'Mendeliome', an in silico panel of genes can be analysed to give similar results to a targeted capture approach, whilst giving the flexibility to 'open' the data if the initial analysis does not find a variant of interest, or in light of novel genetic associations. A similar approach can be utilised with WGS, with the potential advantage of improved coverage, coverage of regulatory and intronic regions and improved analysis of copy number and structural rearrangements, but with the disadvantages of increased cost and substantially increased data and variant volume. 
WES and WGS are hampered by the fact that large numbers of genetic variants are identified, including variants of unknown significance and incidental or secondary findings. These findings raise a number of ethical and practical issues relating to consent, data storage and analysis, all too extensive to cover here. The American College of Medical Genetics and Genomics has published guidance on reporting secondary findings.

When compared to WES or WGS, the cost-effectiveness of NGS using a targeted gene panel analysis has greater clinical application in SRNS, as it produces a more feasible dataset for bioinformatics analysis which is functionally interpretable in a clinical setting.

\section{Application to SRNS}

Currently, clinical phenotyping combined with targeted NGS panel analysis is the most cost-effective and clinically useful approach for mutational screening in SRNS. This method enables clinicians to quantify and stratify likely response to immunosuppression, rate of progression to ESRD and risk of post-transplant reoccurrence. Using NGS technology, most monogenic SRNS genes (approximately $40-50$ genes per panel) can be analysed within 6 weeks and at a competitive price compared to Sanger methods [6,107]. There are several commercial indication-driven SRNS gene panels currently in use around the world, with many laboratories conducting entire or targeted sequence analysis, antenatal testing and carrier screening for SRNS genes. Indeed, an internet search (www. genetests.org) reveals at least 12 laboratories worldwide offering extended NGS panels for SRNS with an average turnaround of 3-6 weeks and associated cost ranging from $\$ 1000$ to $\$ 2200$. Comparatively, Sanger sequencing for individual genes or small panels of genes (approximately 5 genes) has a slightly quicker turnaround of 2-4 weeks and, depending on the size of the gene, costs $\$ 450-\$ 1000$ per individual gene.

In certain circumstances where NGS technology is inaccessible or unaffordable, and a disease-causing mutation is highly likely in a specific gene, as suggested by the presence of extrarenal manifestations or a positive family history, Sanger sequencing methods remain an important diagnostic tool. It is important to stress that employing genotype-phenotype correlations alone to direct mutational screening using Sanger methods is only cost-effective, and clinically beneficial, provided a causative mutation is identified early in the screening process.

\section{Approach to mutational screening}

Our recommended approach to mutational screening in paediatric SRNS is demonstrated in Fig. 2. If NGS techniques are accessible and affordable, an extended SRNS gene panel including, but not limited to, the most common monogenic causes of SRNS for each age group should be screened (Fig. 2). For SRNS presenting in the congenital period, the panel should include the five most likely causative genes (NPHS1, NPHS2, WT1, LAMB2 and PLCE1), and for those presenting in infancy or childhood, the gene panel should also include TRPC6, ACTN4 and ADCK4. Similarly, for those presenting in adolescence, an extended gene panel would maximise the likelihood of identifying a causative mutation, and the panel should include the genes already mentioned, as well as INF2.

Patients with disease-causing mutations in genes encoding enzymes of the coenzyme $\mathrm{Q}_{10}$ pathway $(C O Q 2, C O Q 6$ and $A D C K 4$ ) may be amenable to treatment, and although these represent a rare group of patients, they are important to
Fig. 2 Mutational screening in children with isolated SRNS. If next-generation sequencing (NGS) technology is accessible, screening should utilise a gene panel including, but not limited to, the most common monogenic causes of SRNS. If NGS technology is inaccessible, genes should be screened in numerical order of frequency per age group. Ethnicity and histological findings should trigger preferential screening of certain genes. DMS Diffuse mesangial sclerosis. For names of genes and associated encoded proteins, please refer to Table 1

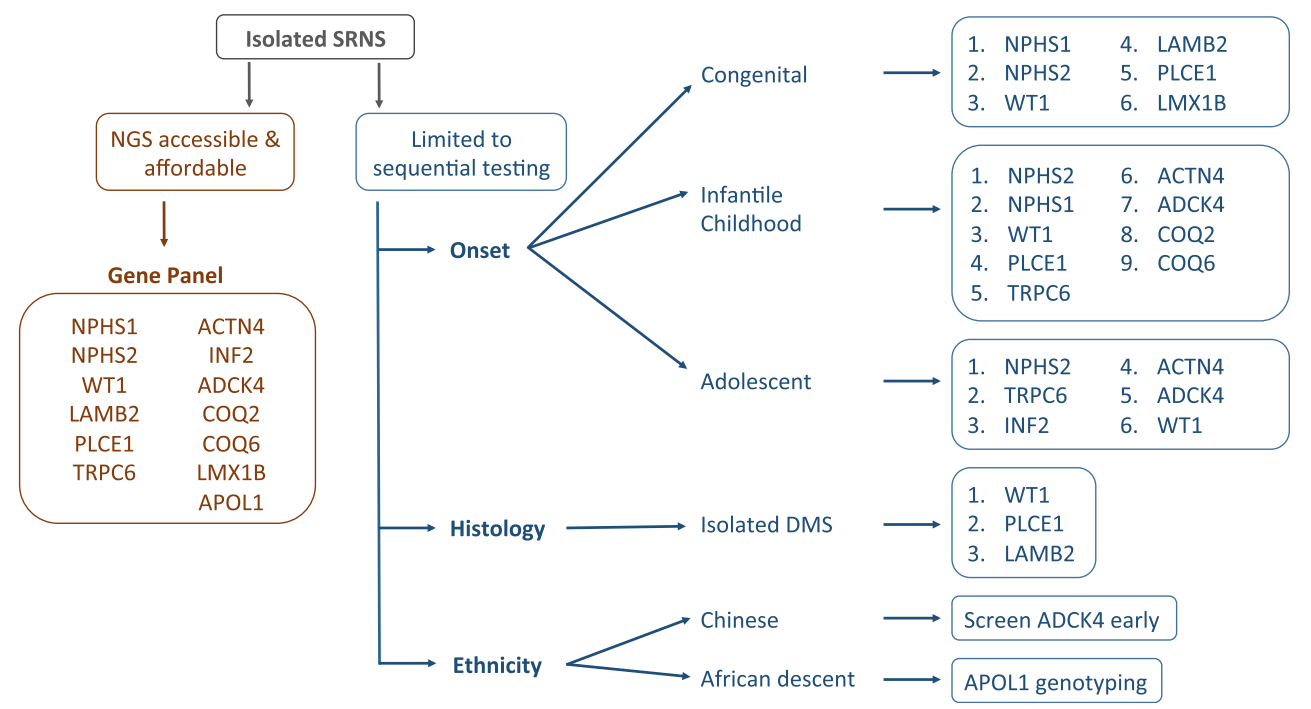


recognise and should therefore be included in the genetic screening panel for isolated SRNS presenting in any paediatric age group, including the first year of life. This is especially true for patients of Chinese, Japanese and Korean origin, as there appears to be an increased frequency of the $A D C K 4$ mutation in these populations [10, 70]. Additionally, given that the APOL1 genotype represents a vulnerable population who present with more advanced disease [108], defining a patient's $A P O L 1$ genotype has important clinical implications, and mutational screening of this gene should be included in the gene panel, especially for patients of African descent.

If NGS technology is neither accessible nor affordable and clinicians are limited to sequential testing, genes should be screened in numerical order, for each age group, as depicted in Fig. 2. If renal histology is available and reveals isolated DMS, we suggest preferentially screening for mutations in WT1, PLCE1 and LAMB2. In the presence of extra-renal manifestations, it is highly likely that a causative mutation will be detected, and genes should be selected for screening depending on the specific phenotype identified (Table 2). In view of the significant complications associated with WT1 mutations, establishing a genetic diagnosis appears to be particularly important; it is therefore advisable to routinely screen $W T 1$ for mutations in isolated SRNS.

With the advent of NGS methods targeting large panels of genes, novel pathogenic variants in genes that are more rarely implicated in paediatric SRNS are being identified. Most recently, mutations in SMARCAL1, CUBN, LMX1B, PODXL and the nucleoporin genes, NUP93 and NUP107, have been found to be causative of isolated SRNS presenting from infancy and throughout childhood $[8,10]$. Moreover, mutations in genes which are usually linked to another renal phenotype (DGKE, OCRL and COL4A3) have been found to be causative of isolated SRNS presenting in childhood [8]. These findings highlight the importance of employing NGS technology in the diagnosis of monogenic SRNS through expanding current knowledge in the pathogenesis and molecular basis of proteinuria. For this reason, extended gene panels and if appropriate resources are available, WES/WGS techniques, should be considered wherever possible.

\section{Conclusion}

Mutations of podocyte-associated genes account for approximately $30 \%$ of paediatric cases of SRNS. The younger the child at presentation, the higher the genetic diagnostic rate. Advances in genomic sequencing have improved our understanding of the molecular basis of NS and of the genetic heterogeneity of SRNS. A genetic diagnosis allows a "personalised" approach when investigating and managing patients and their families. That is, clinicians are more able to make decisions about weaning immunosuppression, avoiding renal biopsy and planning renal transplantation and geneticists can offer more informed genetic counselling. In a small but significant sub-group of patients with specific mutations, a genetic diagnosis may open avenues for interventional disease-modifying therapy and allow clinicians to detect and treat asymptomatic extra-renal manifestations early.

The clinical utility of such advances has been hindered by a lack of clear guidelines pertaining to mutational screening in SRNS. There exists profound clinical and pathological heterogeneity in monogenic SRNS, with mutations in the same gene and even identical mutations resulting in significant phenotypic variability. This heterogeneity renders sequential mutational screening using traditional Sanger sequencing a timely and costly process. Technological advances in genomic sequencing have led to the development of commercial, indication-driven gene panels which simultaneously sequence over 40 known SRNS-related genes. NGS panels are available worldwide, and with a similar turnaround time and slightly increased cost to traditional methods, they currently represent the most time- and costeffective approach to mutational screening in SRNS. We propose that all children presenting with primary SRNS be screened for monogenic causative mutations using an extended gene panel; especially in cases of early-onset disease and those with a positive family history or history of consanguinity. If such an inclusive approach is not possible, we provide recommendations for sequential gene testing which direct the clinician towards the most frequently occurring causative mutation per age group, depending on available histology, presence of extra-renal manifestations and ethnicity.

NGS methods targeting large panels of genes, the whole exome or genome have allowed the identification of novel pathogenic variants and also novel genetic associations implicated in paediatric SRNS. This in turn enables in vitro and in vivo study of podocyte-associated proteins, further unravelling the pathogenic pathways of SRNS and providing important therapeutic targets to guide advanced medical management on a gene-specific basis.

\section{Key summary points}

- Mutations of podocyte-associated proteins account for approximately $30 \%$ of SRNS in childhood.

- The likelihood of detecting a causative mutation is inversely related to age of disease onset.

- Monogenic SRNS displays significant phenotypic heterogeneity in terms of associated renal histology and clinical presentation.

- A definitive molecular diagnosis has important clinical implications, allowing for a personalised treatment approach. 
- Recent advances in high-throughput sequencing have revolutionised genetic testing, and indication-driven gene panel analysis currently represents the most cost-effective approach for mutational screening in SRNS.

- Identification of novel SRNS genes and causative mutations will further unravel the pathogenic pathways of SRNS.

Acknowledgements R.P is an Academic Clinical fellow funded by the National Institute for Health Research (NIHR), H.S. is an Academic Clinical Lecturer funded by NIHR and R.L. is supported by a Wellcome Trust Senior Fellowship award (202860/Z/16/Z).

\section{Compliance with ethical standards}

Conflict of interest The authors declare no conflicts of interests.

Open Access This article is distributed under the terms of the Creative Commons Attribution 4.0 International License (http:// creativecommons.org/licenses/by/4.0/), which permits unrestricted use, distribution, and reproduction in any medium, provided you give appropriate credit to the original author(s) and the source, provide a link to the Creative Commons license, and indicate if changes were made.

\section{References}

1. Wong W (2007) Idiopathic nephrotic syndrome in New Zealand children, demographic, clinical features, initial management and outcome after twelve-month follow-up: results of a three-year national surveillance study. J Paediatr Child Health 43:337-341

2. Filler G, Young E, Geier P, Carpenter B, Drukker A, Feber J (2003) Is there really an increase in non-minimal change nephrotic syndrome in children? Am J Kidney Dis 42:1107-1113

3. Smith JM, Stablein DM, Munoz R, Hebert D, McDonald RA (2007) Contributions of the transplant registry: the 2006 annual report of the north American Pediatric renal trials and collaborative studies (NAPRTCS). Pediatr Transplant 11:366-373

4. Benoit G, Machuca E, Antignac C (2010) Hereditary nephrotic syndrome: a systematic approach for genetic testing and a review of associated podocyte gene mutations. Pediatr Nephrol 25:16211632

5. McCarthy HJ, Saleem MA (2011) Genetics in clinical practice: nephrotic and proteinuric syndromes. Nephron Exp Nephrol 118: e1-e8

6. Giglio S, Provenzano A, Mazzinghi B, Becherucci F, Giunti L, Sansavini G, Ravaglia F, Roperto RM, Farsetti S, Benetti E, Rotondi M, Murer L, Lazzeri E, Lasagni L, Materassi M, Romagnani P (2015) Heterogeneous genetic alterations in sporadic nephrotic syndrome associate with resistance to immunosuppression. J Am Soc Nephrol 26:230-236

7. Hildebrandt F (2010) Genetic kidney diseases. Lancet 375: $1287-1295$

8. Bierzynska A, McCarthy HJ, Soderquest K, Sen ES, Colby E, Ding WY, Nabhan MM, Kerecuk L, Hegde S, Hughes D, Marks S, Feather S, Jones C, Webb NJ, Ognjanovic M, Christian M, Gilbert RD, Sinha MD, Lord GM, Simpson M, Koziell AB, Welsh GI, Saleem MA (2017) Genomic and clinical profiling of a national nephrotic syndrome cohort advocates a precision medicine approach to disease management. Kidney Int 91:937-947
9. Sadowski CE, Lovric S, Ashraf S, Pabst WL, Gee HY, Kohl S, Engelmann S, Vega-Warner V, Fang H, Halbritter J, Somers MJ, Tan W, Shril S, Fessi I, Lifton RP, Bockenhauer D, El-Desoky S, Kari JA, Zenker M, Kemper MJ, Mueller D, Fathy HM, Soliman NA, SRNS Study Group, Hildebrandt F (2015) A single-gene cause in $29.5 \%$ of cases of steroid-resistant nephrotic syndrome. J Am Soc Nephrol 26:1279-1289

10. Wang F, Zhang Y, Mao J, Yu Z, Yi Z, Yu L, Sun J, Wei X, Ding F, Zhang H, Xiao H, Yao Y, Tan W, Lovric S, Ding J, Hildebrandt F (2017) Spectrum of mutations in Chinese children with steroidresistant nephrotic syndrome. Pediatr Nephrol 32:1181-1192

11. Kestila M, Lenkkeri U, Mannikko M, Lamerdin J, McCready P, Putaala H, Ruotsalainen V, Morita T, Nissinen M, Herva R, Kashtan CE, Peltonen L, Holmberg C, Olsen A, Tryggvason K (1998) Positionally cloned gene for a novel glomerular proteinnephrin - is mutated in congenital nephrotic syndrome. Mol Cell $1: 575-582$

12. Boute N, Gribouval O, Roselli S, Benessy F, Lee H, Fuchshuber A, Dahan K, Gubler MC, Niaudet P, Antignac C (2000) NPHS2, encoding the glomerular protein podocin, is mutated in autosomal recessive steroid-resistant nephrotic syndrome. Nat Genet 24:349-354

13. Hinkes B, Wiggins RC, Gbadegesin R, Vlangos CN, Seelow D, Nurnberg G, Garg P, Verma R, Chaib H, Hoskins BE, Ashraf S, Becker C, Hennies HC, Goyal M, Wharram BL, Schachter AD, Mudumana S, Drummond I, Kerjaschki D, Waldherr R, Dietrich A, Ozaltin F, Bakkaloglu A, Cleper R, Basel-Vanagaite L, Pohl M, Griebel M, Tsygin AN, Soylu A, Muller D, Sorli CS, Bunney TD, Katan M, Liu J, Attanasio M, O'Toole JF, Hasselbacher K, Mucha B, Otto EA, Airik R, Kispert A, Kelley GG, Smrcka AV, Gudermann T, Holzman LB, Nurnberg P, Hildebrandt F (2006) Positional cloning uncovers mutations in PLCE1 responsible for a nephrotic syndrome variant that may be reversible. Nat Genet 38: 1397-1405

14. Lowik MM, Groenen PJ, Pronk I, Lilien MR, Goldschmeding R, Dijkman HB, Levtchenko EN, Monnens LA, van den Heuvel LP (2007) Focal segmental glomerulosclerosis in a patient homozygous for a CD2AP mutation. Kidney Int 72:1198-1203

15. Winn MP, Conlon PJ, Lynn KL, Farrington MK, Creazzo T, Hawkins AF, Daskalakis N, Kwan SY, Ebersviller S, Burchette JL, Pericak-Vance MA, Howell DN, Vance JM, Rosenberg PB (2005) A mutation in the TRPC6 cation channel causes familial focal segmental glomerulosclerosis. Science 308:1801-1804

16. Ebarasi L, Ashraf S, Bierzynska A, Gee HY, McCarthy HJ, Lovric S, Sadowski CE, Pabst W, Vega-Warner V, Fang H, Koziell A, Simpson MA, Dursun I, Serdaroglu E, Levy S, Saleem MA, Hildebrandt F, Majumdar A (2015) Defects of CRB2 cause steroid-resistant nephrotic syndrome. Am J Hum Genet 96:153-161

17. Gee HY, Sadowski CE, Aggarwal PK, Porath JD, Yakulov TA, Schueler M, Lovric S, Ashraf S, Braun DA, Halbritter J, Fang H, Airik R, Vega-Warner V, Cho KJ, Chan TA, Morris LG, FfrenchConstant C, Allen N, McNeill H, Buscher R, Kyrieleis H, Wallot M, Gaspert A, Kistler T, Milford DV, Saleem MA, Keng WT, Alexander SI, Valentini RP, Licht C, Teh JC, Bogdanovic R, Koziell A, Bierzynska A, Soliman NA, Otto EA, Lifton RP, Holzman LB, Sibinga NE, Walz G, Tufro A, Hildebrandt F (2016) FAT1 mutations cause a glomerulotubular nephropathy. Nat Commun 7:10822

18. Barbaux S, Niaudet P, Gubler MC, Grunfeld JP, Jaubert F, Kuttenn F, Fekete CN, Souleyreau-Therville N, Thibaud E, Fellous M, McElreavey K (1997) Donor splice-site mutations in WT1 are responsible for Frasier syndrome. Nat Genet 17:467-470

19. Pelletier J, Bruening W, Kashtan CE, Mauer SM, Manivel JC, Striegel JE, Houghton DC, Junien C, Habib R, Fouser L, Fine RN, Silverman BL, Haber DA, Housman D (1991) Germline 
mutations in the Wilms' tumor suppressor gene are associated with abnormal urogenital development in Denys-Drash syndrome. Cell 67:437-447

20. Dreyer SD, Zhou G, Baldini A, Winterpacht A, Zabel B, Cole W, Johnson RL, Lee B (1998) Mutations in LMX1B cause abnormal skeletal patterning and renal dysplasia in Nail Patella syndrome. Nat Genet 19:47-50

21. Boerkoel CF, Takashima H, John J, Yan J, Stankiewicz P, Rosenbarker L, Andre JL, Bogdanovic R, Burguet A, Cockfield S, Cordeiro I, Frund S, Illies F, Joseph M, Kaitila I, Lama G, Loirat C, McLeod DR, Milford DV, Petty EM, Rodrigo F, Saraiva JM, Schmidt B, Smith GC, Spranger J, Stein A, Thiele H, Tizard J, Weksberg R, Lupski JR, Stockton DW (2002) Mutant chromatin remodeling protein SMARCAL1 causes Schimke immuno-osseous dysplasia. Nat Genet 30:215-220

22. Braun DA, Sadowski CE, Kohl S, Lovric S, Astrinidis SA, Pabst WL, Gee HY, Ashraf S, Lawson JA, Shril S, Airik M, Tan W, Schapiro D, Rao J, Choi WI, Hermle T, Kemper MJ, Pohl M, Ozaltin F, Konrad M, Bogdanovic R, Buscher R, Helmchen U, Serdaroglu E, Lifton RP, Antonin W, Hildebrandt F (2016) Mutations in nuclear pore genes NUP93, NUP205 and XPO5 cause steroid-resistant nephrotic syndrome. Nat Genet 48:457-465

23. Miyake N, Tsukaguchi H, Koshimizu E, Shono A, Matsunaga S, Shiina M, Mimura Y, Imamura S, Hirose T, Okudela K, Nozu K, Akioka Y, Hattori M, Yoshikawa N, Kitamura A, Cheong HI, Kagami S, Yamashita M, Fujita A, Miyatake S, Tsurusaki Y, Nakashima M, Saitsu H, Ohashi K, Imamoto N, Ryo A, Ogata K, Iijima K, Matsumoto N (2015) Biallelic mutations in nuclear pore complex subunit NUP107 cause early-childhood-onset steroid-resistant Nephrotic syndrome. Am J Hum Genet 97:555-566

24. Izu A, Yanagida H, Sugimoto K, Fujita S, Sakata N, Wada N, Okada M, Takemura T (2011) Pathogenesis of focal segmental glomerular sclerosis in a girl with the partial deletion of chromosome 6p. Tohoku J Exp Med 223:187-192

25. Esposito T, Lea RA, Maher BH, Moses D, Cox HC, Magliocca S, Angius A, Nyholt DR, Titus T, Kay T, Gray NA, Rastaldi MP, Parnham A, Gianfrancesco F, Griffiths LR (2013) Unique Xlinked familial FSGS with co-segregating heart block disorder is associated with a mutation in the NXF5 gene. Hum Mol Genet 22: 3654-3666

26. Kerti A, Csohany R, Wagner L, Javorszky E, Maka E, Tory K (2013) NPHS2 homozygous p.R229Q variant: potential modifier instead of causal effect in focal segmental glomerulosclerosis. Pediatr Nephrol 28:2061-2064

27. Thong KM, Xu Y, Cook J, Takou A, Wagner B, Kawar B, Ong AC (2013) Cosegregation of focal segmental glomerulosclerosis in a family with familial partial lipodystrophy due to a mutation in LMNA. Nephron Clin Pract 124:31-37

28. Colin E, Huynh Cong E, Mollet G, Guichet A, Gribouval O, Arrondel C, Boyer O, Daniel L, Gubler MC, Ekinci Z, Tsimaratos M, Chabrol B, Boddaert N, Verloes A, Chevrollier A, Gueguen N, Desquiret-Dumas V, Ferre M, Procaccio V, Richard L, Funalot B, Moncla A, Bonneau D, Antignac C (2014) Loss-of-function mutations in WDR73 are responsible for microcephaly and steroid-resistant nephrotic syndrome: Galloway-Mowat syndrome. Am J Hum Genet 95:637-648

29. Kaplan JM, Kim SH, North KN, Rennke H, Correia LA, Tong HQ, Mathis BJ, Rodriguez-Perez JC, Allen PG, Beggs AH, Pollak MR (2000) Mutations in ACTN4, encoding alphaactinin-4, cause familial focal segmental glomerulosclerosis. Nat Genet 24:251-256

30. Kopp JB, Smith MW, Nelson GW, Johnson RC, Freedman BI, Bowden DW, Oleksyk T, McKenzie LM, Kajiyama H, Ahuja TS, Berns JS, Briggs W, Cho ME, Dart RA, Kimmel PL, Korbet
SM, Michel DM, Mokrzycki MH, Schelling JR, Simon E, Trachtman H, Vlahov D, Winkler CA (2008) MYH9 is a major-effect risk gene for focal segmental glomerulosclerosis. Nat Genet 40:1175-1184

31. Boyer O, Benoit G, Gribouval O, Nevo F, Tete MJ, Dantal J, Gilbert-Dussardier B, Touchard G, Karras A, Presne C, Grunfeld JP, Legendre C, Joly D, Rieu P, Mohsin N, Hannedouche T, Moal V, Gubler MC, Broutin I, Mollet G, Antignac C (2011) Mutations in INF2 are a major cause of autosomal dominant focal segmental glomerulosclerosis. J Am Soc Nephrol 22:239-245

32. Mele C, Iatropoulos P, Donadelli R, Calabria A, Maranta R, Cassis P, Buelli S, Tomasoni S, Piras R, Krendel M, Bettoni S, Morigi M, Delledonne M, Pecoraro C, Abbate I, Capobianchi MR, Hildebrandt F, Otto E, Schaefer F, Macciardi F, Ozaltin F, Emre S, Ibsirlioglu T, Benigni A, Remuzzi G, Noris M, PodoNet Consortium (2011) MYO1E mutations and childhood familial focal segmental glomerulosclerosis. N Engl J Med 365:295-306

33. Bierzynska A, Soderquest K, Dean P, Colby E, Rollason R, Jones C, Inward CD, McCarthy HJ, Simpson MA, Lord GM, Williams M, Welsh GI, Koziell AB, Saleem MA, NephroS, UK study of Nephrotic Syndrome (2017) MAGI2 mutations cause congenital Nephrotic syndrome. J Am Soc Nephrol 28:1614-1621

34. Gbadegesin RA, Hall G, Adeyemo A, Hanke N, Tossidou I, Burchette J, Wu G, Homstad A, Sparks MA, Gomez J, Jiang R, Alonso A, Lavin P, Conlon P, Korstanje R, Stander MC, Shamsan G, Barua M, Spurney R, Singhal PC, Kopp JB, Haller H, Howell D, Pollak MR, Shaw AS, Schiffer M, Winn MP (2014) Mutations in the gene that encodes the F-actin binding protein anillin cause FSGS. J Am Soc Nephrol 25:1991-2002

35. Akilesh S, Suleiman H, Yu H, Stander MC, Lavin P, Gbadegesin R, Antignac C, Pollak M, Kopp JB, Winn MP, Shaw AS (2011) Arhgap24 inactivates Rac1 in mouse podocytes, and a mutant form is associated with familial focal segmental glomerulosclerosis. J Clin Invest 121:4127-4137

36. Gee HY, Saisawat P, Ashraf S, Hurd TW, Vega-Warner V, Fang H, Beck BB, Gribouval O, Zhou W, Diaz KA, Natarajan S, Wiggins RC, Lovric S, Chernin G, Schoeb DS, Ovunc B, Frishberg Y, Soliman NA, Fathy HM, Goebel H, Hoefele J, Weber LT, Innis JW, Faul C, Han Z, Washburn J, Antignac C, Levy S, Otto EA, Hildebrandt F (2013) ARHGDIA mutations cause nephrotic syndrome via defective RHO GTPase signaling. J Clin Invest 123: 3243-3253

37. Gee HY, Zhang F, Ashraf S, Kohl S, Sadowski CE, Vega-Warner V, Zhou W, Lovric S, Fang H, Nettleton M, Zhu JY, Hoefele J, Weber LT, Podracka L, Boor A, Fehrenbach H, Innis JW, Washburn J, Levy S, Lifton RP, Otto EA, Han Z, Hildebrandt F (2015) KANK deficiency leads to podocyte dysfunction and nephrotic syndrome. J Clin Invest 125:2375-2384

38. Dai S, Wang Z, Pan X, Wang W, Chen X, Ren H, Hao C, Han B, Chen N (2010) Functional analysis of promoter mutations in the ACTN4 and SYNPO genes in focal segmental glomerulosclerosis. Nephrol Dial Transplant 25:824-835

39. Ozaltin F, Ibsirlioglu T, Taskiran EZ, Baydar DE, Kaymaz F, Buyukcelik M, Kilic BD, Balat A, Iatropoulos P, Asan E, Akarsu NA, Schaefer F, Yilmaz E, Bakkaloglu A, PodoNet Consortium (2011) Disruption of PTPRO causes childhoodonset nephrotic syndrome. Am J Hum Genet 89:139-147

40. Gee HY, Ashraf S, Wan X, Vega-Warner V, Esteve-Rudd J, Lovric S, Fang H, Hurd TW, Sadowski CE, Allen SJ, Otto EA, Korkmaz E, Washburn J, Levy S, Williams DS, Bakkaloglu SA, Zolotnitskaya A, Ozaltin F, Zhou W, Hildebrandt F (2014) Mutations in EMP2 cause childhood-onset nephrotic syndrome. Am J Hum Genet 94:884-890

41. Genovese G, Friedman DJ, Ross MD, Lecordier L, Uzureau P, Freedman BI, Bowden DW, Langefeld CD, Oleksyk TK, Uscinski Knob AL, Bernhardy AJ, Hicks PJ, Nelson GW, 
Vanhollebeke B, Winkler CA, Kopp JB, Pays E, Pollak MR (2010) Association of trypanolytic ApoL1 variants with kidney disease in African Americans. Science 329:841-845

42. Ovunc B, Otto EA, Vega-Warner V, Saisawat P, Ashraf S, Ramaswami G, Fathy HM, Schoeb D, Chernin G, Lyons RH, Yilmaz E, Hildebrandt F (2011) Exome sequencing reveals cubilin mutation as a single-gene cause of proteinuria. J Am Soc Nephrol 22:1815-1820

43. Barua M, Shieh E, Schlondorff J, Genovese G, Kaplan BS, Pollak MR (2014) Exome sequencing and in vitro studies identified podocalyxin as a candidate gene for focal and segmental glomerulosclerosis. Kidney Int 85:124-133

44. Zenker M, Aigner T, Wendler O, Tralau T, Muntefering H, Fenski R, Pitz S, Schumacher V, Royer-Pokora B, Wuhl E, Cochat P, Bouvier R, Kraus C, Mark K, Madlon H, Dotsch J, Rascher W, Maruniak-Chudek I, Lennert T, Neumann LM, Reis A (2004) Human laminin beta2 deficiency causes congenital nephrosis with mesangial sclerosis and distinct eye abnormalities. Hum Mol Genet 13:2625-2632

45. Kambham N, Tanji N, Seigle RL, Markowitz GS, Pulkkinen L, Uitto J, D'Agati VD (2000) Congenital focal segmental glomerulosclerosis associated with beta4 integrin mutation and epidermolysis bullosa. Am J Kidney Dis 36:190-196

46. Has C, Sparta G, Kiritsi D, Weibel L, Moeller A, Vega-Warner V, Waters A, He Y, Anikster Y, Esser P, Straub BK, Hausser I, Bockenhauer D, Dekel B, Hildebrandt F, Bruckner-Tuderman L, Laube GF (2012) Integrin alpha3 mutations with kidney, lung, and skin disease. N Engl J Med 366:1508-1514

47. Voskarides K, Damianou L, Neocleous V, Zouvani I, Christodoulidou S, Hadjiconstantinou V, Ioannou K, Athanasiou Y, Patsias C, Alexopoulos E, Pierides A, Kyriacou K, Deltas C (2007) COL4A3/COL4A4 mutations producing focal segmental glomerulosclerosis and renal failure in thin basement membrane nephropathy. J Am Soc Nephrol 18:3004-3016

48. Okamoto K, Tokunaga K, Doi K, Fujita T, Suzuki H, Katoh T, Watanabe T, Nishida N, Mabuchi A, Takahashi A, Kubo M, Maeda S, Nakamura Y, Noiri E (2011) Common variation in GPC5 is associated with acquired nephrotic syndrome. Nat Genet 43:459-463

49. Karamatic Crew V, Burton N, Kagan A, Green CA, Levene C, Flinter F, Brady RL, Daniels G, Anstee DJ (2004) CD151, the first member of the tetraspanin (TM4) superfamily detected on erythrocytes, is essential for the correct assembly of human basement membranes in kidney and skin. Blood 104:2217-2223

50. Salviati L, Sacconi S, Murer L, Zacchello G, Franceschini L, Laverda AM, Basso G, Quinzii C, Angelini C, Hirano M, Naini AB, Navas P, DiMauro S, Montini G (2005) Infantile encephalomyopathy and nephropathy with CoQ10 deficiency: a CoQ10responsive condition. Neurology 65:606-608

51. Heeringa SF, Chernin G, Chaki M, Zhou W, Sloan AJ, Ji Z, Xie LX, Salviati L, Hurd TW, Vega-Warner V, Killen PD, Raphael Y, Ashraf S, Ovunc B, Schoeb DS, McLaughlin HM, Airik R, Vlangos CN, Gbadegesin R, Hinkes B, Saisawat P, Trevisson E, Doimo M, Casarin A, Pertegato V, Giorgi G, Prokisch H, Rotig A, Nurnberg G, Becker C, Wang S, Ozaltin F, Topaloglu R, Bakkaloglu A, Bakkaloglu SA, Muller D, Beissert A, Mir S, Berdeli A, Varpizen S, Zenker M, Matejas V, Santos-Ocana C, Navas P, Kusakabe T, Kispert A, Akman S, Soliman NA, Krick S, Mundel P, Reiser J, Nurnberg P, Clarke CF, Wiggins RC, Faul $\mathrm{C}$, Hildebrandt $\mathrm{F}$ (2011) COQ6 mutations in human patients produce nephrotic syndrome with sensorineural deafness. J Clin Invest 121:2013-2024

52. Lopez LC, Schuelke M, Quinzii CM, Kanki T, Rodenburg RJ, Naini A, Dimauro S, Hirano M (2006) Leigh syndrome with nephropathy and CoQ10 deficiency due to decaprenyl diphosphate synthase subunit 2 (PDSS2) mutations. Am J Hum Genet 79: $1125-1129$

53. Ashraf S, Gee HY, Woerner S, Xie LX, Vega-Warner V, Lovric S, Fang H, Song X, Cattran DC, Avila-Casado C, Paterson AD, Nitschke P, Bole-Feysot C, Cochat P, Esteve-Rudd J, Haberberger B, Allen SJ, Zhou W, Airik R, Otto EA, Barua M, Al-Hamed MH, Kari JA, Evans J, Bierzynska A, Saleem MA, Bockenhauer D, Kleta R, El Desoky S, Hacihamdioglu DO, Gok F, Washburn J, Wiggins RC, Choi M, Lifton RP, Levy S, Han Z, Salviati L, Prokisch H, Williams DS, Pollak M, Clarke CF, Pei Y, Antignac C, Hildebrandt F (2013) ADCK4 mutations promote steroid-resistant nephrotic syndrome through CoQ10 biosynthesis disruption. J Clin Invest 123:5179-5189

54. Yasukawa T, Suzuki T, Ueda T, Ohta S, Watanabe K (2000) Modification defect at anticodon wobble nucleotide of mitochondrial tRNAs(Leu)(UUR) with pathogenic mutations of mitochondrial myopathy, encephalopathy, lactic acidosis, and stroke-like episodes. J Biol Chem 275:4251-4257

55. Berkovic SF, Dibbens LM, Oshlack A, Silver JD, Katerelos M, Vears DF, Lullmann-Rauch R, Blanz J, Zhang KW, Stankovich J, Kalnins RM, Dowling JP, Andermann E, Andermann F, Faldini E, D'Hooge R, Vadlamudi L, Macdonell RA, Hodgson BL, Bayly MA, Savige J, Mulley JC, Smyth GK, Power DA, Saftig P, Bahlo M (2008) Array-based gene discovery with three unrelated subjects shows SCARB2/LIMP-2 deficiency causes myoclonus epilepsy and glomerulosclerosis. Am J Hum Genet 82:673-684

56. Kaneko K, Hasui M, Hata A, Hata D, Nozu K (2010) Focal segmental glomerulosclerosis in a boy with Dent-2 disease. Pediatr Nephrol 25:781-782

57. Agarwal AK, Zhou XJ, Hall RK, Nicholls K, Bankier A, Van Esch H, Fryns JP, Garg A (2006) Focal segmental glomerulosclerosis in patients with mandibuloacral dysplasia owing to ZMPSTE24 deficiency. J Investig Med 54:208-213

58. van der Knaap MS, Wevers RA, Monnens L, Jakobs C, Jaeken J, van Wijk JA (1996) Congenital nephrotic syndrome: a novel phenotype of type I carbohydrate-deficient glycoprotein syndrome. J Inherit Metab Dis 19:787-791

59. Kranz C, Denecke J, Lehle L, Sohlbach K, Jeske S, Meinhardt F, Rossi R, Gudowius S, Marquardt T (2004) Congenital disorder of glycosylation type Ik (CDG-Ik): a defect of mannosyltransferase I. Am J Hum Genet 74:545-551

60. Huynh Cong E, Bizet AA, Boyer O, Woerner S, Gribouval O, Filhol E, Arrondel C, Thomas S, Silbermann F, Canaud G, Hachicha J, Ben Dhia N, Peraldi MN, Harzallah K, Iftene D, Daniel L, Willems M, Noel LH, Bole-Feysot C, Nitschke P, Gubler MC, Mollet G, Saunier S, Antignac C (2014) A homozygous missense mutation in the ciliary gene TTC21B causes familial FSGS. J Am Soc Nephrol 25:2435-2443

61. Sethi S, Fervenza FC, Zhang Y, Smith RJ (2012) Secondary focal and segmental glomerulosclerosis associated with singlenucleotide polymorphisms in the genes encoding complement factor $\mathrm{H}$ and $\mathrm{C} 3$. Am J Kidney Dis 60:316-321

62. Ozaltin F, Li B, Rauhauser A, An SW, Soylemezoglu O, Gonul II, Taskiran EZ, Ibsirlioglu T, Korkmaz E, Bilginer Y, Duzova A, Ozen S, Topaloglu R, Besbas N, Ashraf S, Du Y, Liang C, Chen P, Lu D, Vadnagara K, Arbuckle S, Lewis D, Wakeland B, Quigg RJ, Ransom RF, Wakeland EK, Topham MK, Bazan NG, Mohan C, Hildebrandt F, Bakkaloglu A, Huang CL, Attanasio M (2013) DGKE variants cause a glomerular microangiopathy that mimics membranoproliferative GN. J Am Soc Nephrol 24:377-384

63. Conlon PJ, Lynn K, Winn MP, Quarles LD, Bembe ML, PericakVance M, Speer M, Howell DN (1999) Spectrum of disease in familial focal and segmental glomerulosclerosis. Kidney Int 56: 1863-1871 
64. Akchurin O, Reidy KJ (2015) Genetic causes of proteinuria and nephrotic syndrome: impact on podocyte pathobiology. Pediatr Nephrol 30:221-233

65. Santin S, Bullich G, Tazon-Vega B, Garcia-Maset R, Gimenez I, Silva I, Ruiz P, Ballarin J, Torra R, Ars E (2011) Clinical utility of genetic testing in children and adults with steroid-resistant nephrotic syndrome. Clin J Am Soc Nephrol 6:1139-1148

66. Hinkes BG, Mucha B, Vlangos CN, Gbadegesin R, Liu J, Hasselbacher K, Hangan D, Ozaltin F, Zenker M, Hildebrandt F, Arbeitsgemeinschaft fur Paediatrische Nephrologie Study Group (2007) Nephrotic syndrome in the first year of life: two thirds of cases are caused by mutations in 4 genes (NPHS1, NPHS2, WT1, and LAMB2). Pediatrics 119:e907-e919

67. Koziell A, Grech V, Hussain S, Lee G, Lenkkeri U, Tryggvason K, Scambler P (2002) Genotype/phenotype correlations of NPHS1 and NPHS2 mutations in nephrotic syndrome advocate a functional inter-relationship in glomerular filtration. Hum Mol Genet 11: 379-388

68. Santin S, Tazon-Vega B, Silva I, Cobo MA, Gimenez I, Ruiz P, Garcia-Maset R, Ballarin J, Torra R, Ars E, FSGS Spanish Study Group (2011) Clinical value of NPHS2 analysis in early- and adult-onset steroid-resistant nephrotic syndrome. Clin J Am Soc Nephrol 6:344-354

69. Weber S, Gribouval O, Esquivel EL, Moriniere V, Tete MJ, Legendre C, Niaudet P, Antignac C (2004) NPHS2 mutation analysis shows genetic heterogeneity of steroid-resistant nephrotic syndrome and low post-transplant recurrence. Kidney Int 66: 571-579

70. Sako M, Nakanishi K, Obana M, Yata N, Hoshii S, Takahashi S, Wada N, Takahashi Y, Kaku Y, Satomura K, Ikeda M, Honda M, Iijima K, Yoshikawa N (2005) Analysis of NPHS1, NPHS2, ACTN4, and WT1 in Japanese patients with congenital nephrotic syndrome. Kidney Int 67:1248-1255

71. Philippe A, Nevo F, Esquivel EL, Reklaityte D, Gribouval O, Tete MJ, Loirat C, Dantal J, Fischbach M, Pouteil-Noble C, Decramer S, Hoehne M, Benzing T, Charbit M, Niaudet P, Antignac C (2008) Nephrin mutations can cause childhood-onset steroid-resistant nephrotic syndrome. J Am Soc Nephrol 19:1871-1878

72. Santin S, Garcia-Maset R, Ruiz P, Gimenez I, Zamora I, Pena A, Madrid A, Camacho JA, Fraga G, Sanchez-Moreno A, Cobo MA, Bernis C, Ortiz A, de Pablos AL, Pintos G, Justa ML, HidalgoBarquero E, Fernandez-Llama P, Ballarin J, Ars E, Torra R, FSGS Spanish Study Group (2009) Nephrin mutations cause childhoodand adult-onset focal segmental glomerulosclerosis. Kidney Int 76:1268-1276

73. Gbadegesin R, Hinkes BG, Hoskins BE, Vlangos CN, Heeringa SF, Liu J, Loirat C, Ozaltin F, Hashmi S, Ulmer F, Cleper R, Ettenger R, Antignac C, Wiggins RC, Zenker M, Hildebrandt $\mathrm{F}$ (2008) Mutations in PLCE1 are a major cause of isolated diffuse mesangial sclerosis (IDMS). Nephrol Dial Transplant 23:1291-1297

74. Ismaili K, Pawtowski A, Boyer O, Wissing KM, Janssen F, Hall M (2009) Genetic forms of nephrotic syndrome: a single-center experience in Brussels. Pediatr Nephrol 24:287-294

75. Lipska BS, Ranchin B, Iatropoulos P, Gellermann J, Melk A, Ozaltin F, Caridi G, Seeman T, Tory K, Jankauskiene A, Zurowska A, Szczepanska M, Wasilewska A, Harambat J, Trautmann A, Peco-Antic A, Borzecka H, Moczulska A, Saeed B, Bogdanovic R, Kalyoncu M, Simkova E, Erdogan O, Vrljicak K, Teixeira A, Azocar M, Schaefer F (2014) Genotype-phenotype associations in WT1 glomerulopathy. Kidney Int 85:1169-1178

76. Lipska BS, Iatropoulos P, Maranta R, Caridi G, Ozaltin F, Anarat A, Balat A, Gellermann J, Trautmann A, Erdogan O, Saeed B, Emre S, Bogdanovic R, Azocar M, Balasz-Chmielewska I, Benetti E, Caliskan S, Mir S, Melk A, Ertan P, Baskin E, Jardim H, Davitaia T, Wasilewska A, Drozdz D, Szczepanska M,
Jankauskiene A, Higuita LM, Ardissino G, Ozkaya O, KuzmaMroczkowska E, Soylemezoglu O, Ranchin B, Medynska A, Tkaczyk M, Peco-Antic A, Akil I, Jarmolinski T, FirsztAdamczyk A, Dusek J, Simonetti GD, Gok F, Gheissari A, Emma F, Krmar RT, Fischbach M, Printza N, Simkova E, Mele C, Ghiggeri GM, Schaefer F (2013) Genetic screening in adolescents with steroid-resistant nephrotic syndrome. Kidney Int 84: 206-213

77. Santin S, Ars E, Rossetti S, Salido E, Silva I, Garcia-Maset R, Gimenez I, Ruiz P, Mendizabal S, Luciano Nieto J, Pena A, Camacho JA, Fraga G, Cobo MA, Bernis C, Ortiz A, de Pablos AL, Sanchez-Moreno A, Pintos G, Mirapeix E, Fernandez-Llama P, Ballarin J, Torra R, Group FS, Zamora I, Lopez-Hellin J, Madrid A, Ventura C, Vilalta R, Espinosa L, Garcia C, Melgosa M, Navarro M, Gimenez A, Cots JV, Alexandra S, Caramelo C, Egido J, San Jose MD, de la Cerda F, Sala P, Raspall F, Vila A, Daza AM, Vazquez M, Ecija JL, Espinosa M, Justa ML, Poveda R, Aparicio C, Rosell J, Muley R, Montenegro J, Gonzalez D, Hidalgo E, de Frutos DB, Trillo E, Gracia S, de los Rios FJ (2009) TRPC6 mutational analysis in a large cohort of patients with focal segmental glomerulosclerosis. Nephrol Dial Transplant 24:3089-3096

78. Barua M, Brown EJ, Charoonratana VT, Genovese G, Sun H, Pollak MR (2013) Mutations in the INF2 gene account for a significant proportion of familial but not sporadic focal and segmental glomerulosclerosis. Kidney Int 83:316-322

79. Heeringa SF, Moller CC, Du J, Yue L, Hinkes B, Chernin G, Vlangos CN, Hoyer PF, Reiser J, Hildebrandt F (2009) A novel TRPC6 mutation that causes childhood FSGS. PLoS One 4:e7771

80. Sadowski CE, Lovric S, Ashraf S, Pabst WL, Gee HY, Kohl S, Engelmann S, Vega-Warner V, Fang H, Halbritter J, Somers MJ, Tan W, Shril S, Fessi I, Lifton RP, Bockenhauer D, El-Desoky S, Kari JA, Zenker M, Kemper MJ, Mueller D, Fathy HM, Soliman NA, Hildebrandt F (2015) A single-gene cause in $29.5 \%$ of cases of steroid-resistant nephrotic syndrome. J Am Soc Nephrol 26: 1279-1289

81. Pollak MR, Alexander MP, Henderson JM (2007) A case of familial kidney disease. Clin J Am Soc Nephrol 2:1367-1374

82. Weins A, Kenlan P, Herbert S, Le TC, Villegas I, Kaplan BS, Appel GB, Pollak MR (2005) Mutational and biological analysis of alpha-actinin-4 in focal segmental glomerulosclerosis. J Am Soc Nephrol 16:3694-3701

83. Brown EJ, Schlondorff JS, Becker DJ, Tsukaguchi H, Tonna SJ, Uscinski AL, Higgs HN, Henderson JM, Pollak MR (2010) Mutations in the formin gene INF2 cause focal segmental glomerulosclerosis. Nat Genet 42:72-76

84. Boyer O, Nevo F, Plaisier E, Funalot B, Gribouval O, Benoit G, Huynh Cong E, Arrondel C, Tete MJ, Montjean R, Richard L, Karras A, Pouteil-Noble C, Balafrej L, Bonnardeaux A, Canaud G, Charasse C, Dantal J, Deschenes G, Deteix P, Dubourg O, Petiot P, Pouthier D, Leguern E, Guiochon-Mantel A, Broutin I, Gubler MC, Saunier S, Ronco P, Vallat JM, Alonso MA, Antignac C, Mollet G (2011) INF2 mutations in Charcot-Marie-tooth disease with glomerulopathy. N Engl J Med 365:2377-2388

85. Tory K, Menyhard DK, Woerner S, Nevo F, Gribouval O, Kerti A, Straner P, Arrondel C, Huynh Cong E, Tulassay T, Mollet G, Perczel A, Antignac C (2014) Mutation-dependent recessive inheritance of NPHS2-associated steroid-resistant nephrotic syndrome. Nat Genet 46:299-304

86. Chernin G, Vega-Warner V, Schoeb DS, Heeringa SF, Ovunc B, Saisawat P, Cleper R, Ozaltin F, Hildebrandt F, Members of the GPN Study Group (2010) Genotype/phenotype correlation in nephrotic syndrome caused by WT1 mutations. Clin J Am Soc Nephrol 5:1655-1662

87. Matejas V, Hinkes B, Alkandari F, Al-Gazali L, Annexstad E, Aytac MB, Barrow M, Blahova K, Bockenhauer D, Cheong HI, 
Maruniak-Chudek I, Cochat P, Dotsch J, Gajjar P, Hennekam RC, Janssen F, Kagan M, Kariminejad A, Kemper MJ, Koenig J, Kogan J, Kroes HY, Kuwertz-Broking E, Lewanda AF, Medeira A, Muscheites J, Niaudet P, Pierson M, Saggar A, Seaver L, Suri M, Tsygin A, Wuhl E, Zurowska A, Uebe S, Hildebrandt F, Antignac C, Zenker M (2010) Mutations in the human laminin beta2 (LAMB2) gene and the associated phenotypic spectrum. Hum Mutat 31:992-1002

88. Hasselbacher K, Wiggins RC, Matejas V, Hinkes BG, Mucha B, Hoskins BE, Ozaltin F, Nurnberg G, Becker C, Hangan D, Pohl M, Kuwertz-Broking E, Griebel M, Schumacher V, Royer-Pokora B, Bakkaloglu A, Nurnberg P, Zenker M, Hildebrandt F (2006) Recessive missense mutations in LAMB2 expand the clinical spectrum of LAMB2-associated disorders. Kidney Int 70:1008-1012

89. Boyer O, Woerner S, Yang F, Oakeley EJ, Linghu B, Gribouval O, Tete MJ, Duca JS, Klickstein L, Damask AJ, Szustakowski JD, Heibel F, Matignon M, Baudouin V, Chantrel F, Champigneulle J, Martin L, Nitschke P, Gubler MC, Johnson KJ, Chibout SD, Antignac C (2013) LMX1B mutations cause hereditary FSGS without extrarenal involvement. J Am Soc Nephrol 24:1216-1222

90. Montini G, Malaventura C, Salviati L (2008) Early coenzyme Q10 supplementation in primary coenzyme Q10 deficiency. N Engl J Med 358:2849-2850

91. Buscher AK, Kranz B, Buscher R, Hildebrandt F, Dworniczak B, Pennekamp P, Kuwertz-Broking E, Wingen AM, John U, Kemper M, Monnens L, Hoyer PF, Weber S, Konrad M (2010) Immunosuppression and renal outcome in congenital and pediatric steroid-resistant nephrotic syndrome. Clin J Am Soc Nephrol 5: 2075-2084

92. Gellermann J, Stefanidis CJ, Mitsioni A, Querfeld U (2010) Successful treatment of steroid-resistant nephrotic syndrome associated with WT1 mutations. Pediatr Nephrol 25:1285-1289

93. Ruf RG, Lichtenberger A, Karle SM, Haas JP, Anacleto FE, Schultheiss M, Zalewski I, Imm A, Ruf EM, Mucha B, Bagga A, Neuhaus T, Fuchshuber A, Bakkaloglu A, Hildebrandt F, Arbeitsgemeinschaft Fur Padiatrische Nephrologie Study Group (2004) Patients with mutations in NPHS2 (podocin) do not respond to standard steroid treatment of nephrotic syndrome. J Am Soc Nephrol 15:722-732

94. Faul C, Donnelly M, Merscher-Gomez S, Chang YH, Franz S, Delfgaauw J, Chang JM, Choi HY, Campbell KN, Kim K, Reiser J, Mundel P (2008) The actin cytoskeleton of kidney podocytes is a direct target of the antiproteinuric effect of cyclosporine A. Nat Med 14:931-938

95. Trautmann A, Bodria M, Ozaltin F, Gheisari A, Melk A, Azocar M, Anarat A, Caliskan S, Emma F, Gellermann J, Oh J, Baskin E, Ksiazek J, Remuzzi G, Erdogan O, Akman S, Dusek J, Davitaia T, Ozkaya O, Papachristou F, Firszt-Adamczyk A, Urasinski T, Testa S, Krmar RT, Hyla-Klekot L, Pasini A, Ozcakar ZB, Sallay P, Cakar N, Galanti M, Terzic J, Aoun B, Caldas Afonso A,
Szymanik-Grzelak H, Lipska BS, Schnaidt S, Schaefer F, PodoNet Consortium (2015) Spectrum of steroid-resistant and congenital nephrotic syndrome in children: the PodoNet registry cohort. Clin J Am Soc Nephrol 10:592-600

96. Maas RJ, Deegens JK, van den Brand JA, Cornelissen EA, Wetzels JF (2013) A retrospective study of focal segmental glomerulosclerosis: clinical criteria can identify patients at high risk for recurrent disease after first renal transplantation. BMC Nephrol 14:47

97. Weber S, Tonshoff B (2005) Recurrence of focal-segmental glomerulosclerosis in children after renal transplantation: clinical and genetic aspects. Transplantation 80:S128-S134

98. Konigshausen E, Sellin L (2016) Circulating permeability factors in primary focal segmental Glomerulosclerosis: a review of proposed candidates. Biomed Res Int 2016:3765608

99. Wada T, Nangaku M (2015) A circulating permeability factor in focal segmental glomerulosclerosis: the hunt continues. Clin Kidney J 8:708-715

100. Green RC, Lautenbach D, McGuire AL (2015) GINA, genetic discrimination, and genomic medicine. $\mathrm{N}$ Engl J Med 372:397-399

101. Aswini YB, Varun S (2010) Genetics in public health: rarely explored. Indian J Hum Genet 16:47-54

102. Spoonamore KG, Johnson NM (2016) Who pays? Coverage challenges for cardiovascular genetic testing in U.S. patients. Front Cardiovasc Med 3:14

103. Trosman JR, Weldon CB, Douglas MP, Kurian AW, Kelley RK, Deverka PA, Phillips KA (2017) Payer coverage for hereditary cancer panels: barriers, opportunities, and implications for the precision medicine initiative. J Natl Compr Cancer Netw 15:219-228

104. Robinson JO, Carroll TM, Feuerman LZ, Perry DL, HoffmanAndrews L, Walsh RC, Christensen KD, Green RC, McGuire AL (2016) Participants and study Decliners' perspectives about the risks of participating in a clinical trial of whole genome sequencing. J Empir Res Hum Res Ethics 11:21-30

105. Lovric S, Ashraf S, Tan W, Hildebrandt F (2016) Genetic testing in steroid-resistant nephrotic syndrome: when and how? Nephrol Dial Transplant 31:1802-1813

106. Brown EJ, Pollak MR, Barua M (2014) Genetic testing for nephrotic syndrome and FSGS in the era of next-generation sequencing. Kidney Int 85:1030-1038

107. Ha TS (2017) Genetics of hereditary nephrotic syndrome: a clinical review. Korean J Pediatr 60:55-63

108. Sampson MG, Robertson CC, Martini S, Mariani LH, Lemley KV, Gillies CE, Otto EA, Kopp JB, Randolph A, Vega-Warner V, Eichinger F, Nair V, Gipson DS, Cattran DC, Johnstone DB, O'Toole JF, Bagnasco SM, Song PX, Barisoni L, Troost JP, Kretzler M, Sedor JR (2016) Integrative genomics identifies novel associations with APOL1 risk genotypes in black NEPTUNE subjects. J Am Soc Nephrol 27:814-823 